\title{
FAKTOR RISIKO YANG BERHUBUNGAN DENGAN KEJADIAN KANKER PAYUDARA DI RUMAH SAKIT UMUM DAERAH dr. H. ABDUL MOELOEK PROVINSI LAMPUNG
}

\author{
Rina Suryani ${ }^{1}$ Hery Djoko Subandriyo ${ }^{2}$ Dhiny Easter Yanti $^{2}$ \\ ${ }^{1}$ Mahasiswa Program Studi Magister Kesehatan Masyarakat Universitas Malahayati Bandar Lampung \\ ${ }^{2}$ Dosen Fakultas Kesehatan Masyarakat Universitas Malahayati Bandar Lampung \\ Email: rinasuryani627@gmail.com
}

\begin{abstract}
Risk Factor Related to Breast Cancer Incident in General Hospital dr. H. ABDUL Moeloek Lampung. Data on the incidence of breast cancer in 2014 at the Regional General Hospital dr. H. Abdul Moeloek Bandar Lampung as many as 1,347 people, while data on outpatient during 2014 as many as 3,500 people. This research uses a quantitative method with cross sectional study design. The study population of all patients who visit the hospital either outpatient care during the study period as many as 1,347 people. The sample was 99 people. The sampling technique using simple random sampling method. Data analysis was performed using chi-square and logistic regression. The results showed that there is influence of genetic factors ( $\mathrm{p}$ value $=0.000)$, age $(p$-value $=0.000)$, early menarche $(p$-value $=0.001)$, use of contraception $(p-$ value $=0.012)$ and obesity $(p$-value $=0.012)$ on the incidence of breast cancer in the Regional General Hospital dr. H. Abdul Moeloek Bandar Lampung in 2014. The most influential factor on the incidence of breast cancer in the Regional General Hospital dr. H. Abdul Moeloek Bandar Lampung in 2014 is the age factor with $\mathrm{OR}=12.769$. Advice, respondents expected to increase their knowledge about BSE, especially with age where age $>50$ years is the age most susceptible to breast cancer. Results of this study are expected to be used as input and the recommendation to health institution, especially the units closest to the public health services to improve health education programs in particular about early detection of breast cancer by providing counseling to mothers to prevent and reviews with breast cancer.
\end{abstract}

Keywords: Risk factors, Breast cancer

\begin{abstract}
Abstrak: Faktor Resiko yang Berhubungan dengan Kejadian Kanker Payudara di Rumah Sakit Umum Daerah dr. H.Abdoel Moeloek Provinsi Lampung. Data pada tahun 2014 kejadian kanker payudara di Rumah Sakit Umum Daerah dr. H. Abdul Moeloek Bandar Lampung sebanyak 1.347 orang, sedangkan data rawat jalan selama tahun 2014 sebanyak 3.500 orang. Jenis penelitian ini menggunakan metode kuantitatif dengan rancangan penelitian cross sectional. Populasi penelitian semua pasien yang mengunjungi Rumah Sakit baik rawat jalan selama periode penelitian sebanyak 1.347 orang. Sampel penelitian adalah 99 orang. Tehnik pengambilan sampel menggunakan metode simple random sampling. Analisis data dilakukan dengan chi square dan regresi logistik. Hasil penelitian menunjukkan bahwa ada hubungan faktor genetik ( $p$-value= $0,000)$, usia $(p$-value $=0,000)$, menarche dini $(p$-value $=0,001)$, penggunaan kontrasepsi $(p$-value $=$ $0,012)$ dan obsesitas $(p$-value $=0,012)$ terhadap kejadian kanker payudara di Rumah Sakit Umum Daerah dr. H. Abdul Moeloek Bandar Lampung tahun 2014. Faktor yang paling berhubungan terhadap kejadian kanker payudara di Rumah Sakit Umum Daerah dr. H. Abdul Moeloek Bandar Lampung tahun 2014 adalah faktor usia dengan $\mathrm{OR}=12,769$. Saran, responden diharapkan dapat meningkatkan pengetahuannya tentang Sadari, terutama dengan memperahtikan usia dimana usia $>50$ tahun merupakan usia paling rentan terhadap kejadian kanker payudara. Hasil penelitian ini diharapkan dapat dijadikan masukan dan rekomendasi kepada instansi kesehatan terutama unitunit pelayanan kesehatan terdekat dengan masyarakat untuk lebih meningkatkan program penyuluhan kesehatan khususnya tentang deteksi dini kanker payudara dengan cara memberikan penyuluhan kepada ibu-ibu dalam mencegah dan menanggulangi kanker payudara.
\end{abstract}

Kata kunci: Faktor risiko, Kanker payudara

Kanker payudara merupakan salah satu penyakit tidak menular dan jenis kanker yang sering diderita kaum wanita. Kanker payudara menjadi masalah kesehatan reproduksi, baik di dunia maupun di Indonesia yang kini menjadi perhatian serius. Kanker payudara merupakan 
salah satu penyebab utama kematian yang diakibatkan oleh kanker pada wanita di seluruh dunia (Setiati, 2009).

Menurut World Health Organization (WHO), secara global angka penderita kanker payudara terus mengalami peningkatan. Hingga saat ini kanker payudara masih merupakan kanker paling mematikan bagi wanita. Menurut WHO $8-9 \%$ wanita akan mengalami kanker payudara. Tahun 2000 diperkirakan 1,2 juta wanita terdiagnosis kanker payudara dan lebih dari 700,000 meninggal karenanya. Tahun 2004 diperkirakan bahwa 519.000 wanita meninggal karena kanker payudara. Sedangkan menurut International Agency for Research on Cancer (IARC) tahun 2008 ada 1,38 juta kasus baru dan 458.000 meninggal setiap tahunnya. Disusul tahun 2010 terdapat 1,6 juta perempuan yang terdiagnosa (Kemenkes RI, 2013).

Menurut data International Agency for Research on Cancer (IARC) tahun 2012, kanker payudara sebesar 40 per 100.000 perempuan. Mengingat adanya kecenderungan peningkatan jumlah penderita kanker payudara, maka perlu dilakukan upaya untuk pencegahan kanker payudara. Menteri Kesehatan RI pada pembukaan seminar sehari dalam rangka memperingati hari kanker sedunia tahun 2013 menyampaikan bahwa sejak 2014, Kemenkes RI telah melaksanakan program deteksi dini kanker payudara yang dikenal dengan program see and treat (temukan dan tangani), melalui metode Clinical Breast Examination (CBE) untuk deteksi dini kanker payudara ataupun dengan metode SADARI (pemeriksaan payudara sendiri). Program pencegahan melalui deteksi dini dan skrining penyakit tidak menular termasuk kanker juga telah dikembangkan kementerian kesehatan melalui perilaku Cerdik. C berarti Cek kesehatan secara berkala, E berarti Enyahkan asap rokok, R berarti Rajin berolah raga/beraktivitas fisik, D berarti Diet yang sehat dengan banyak mengkonsumsi buah dan sayur dengan kalori seimbang, I berarti Istirahat yang cukup, K berarti Kelola stress dengan baik (Kemenkes RI, 2013).

Profil kesehatan Departemen Kesehatan Republik Indonesia Tahun 2014 menunjukkan kanker tertinggi yang diderita wanita Indonesia adalah kanker payudara dengan angka kejadian 26 per 100.000 perempuan. Angka yang sama ditunjukkan oleh data dari Sistem Informasi Rumah Sakit (SIRS) tahun 2014, kanker payudara menempati urutan pertama pada pasien rawat inap di seluruh RS di Indonesia dengan angka kejadian 26 per 100.000 perempuan $(16,85 \%)$. Tahun 2010 kanker payudara dan kanker leher rahim kembali mendominasi pada pasien rawat inap maupun rawat jalan di seluruh RS di Indonesia, dengan proporsi sebesar 28,7\% untuk kanker payudara, dan kanker leher rahim 12,8\% (Kemenkes RI, 2013).

Menurut data RSUDAM sebanyak 597 pasien terdiagnosis menderita tumor payudara. Jumlah tersebut selama 10 bulan dari Januari hingga Oktober 2014. Sebanyak 152 di antaranya terdeteksi sebagai tumor ganas (kanker), dan 372 lainnya tumor jinak. Sedangkan 73 sisanya diketahui hanya terinfeksi tumor KGB (kelenjar getah bening). Limfoid juga banyak ditemukan, totalnya ada 320 kasus. Rincinya, 96 kasus sebagai kanker (tumor ganas), 207 tumor jinak dan 17 kasus terinfeksi. Sedangak tumor jaringan lunak ada 309 kasus, dengan yang ditemukan ganas sebanyak 98 kasus. Jenis penyakit tumor lain yang sering didapati yakni seperti ovarium (92 kasus), tumor leher (229 kasus), tumor antrum (55 kasus), tumor paru (64 kasus), prostat (63 kasus), dan serviks (80 kasus) (RSUDAM Provinsi Lampung, 2014).

Kanker payudara merupakan kesehatan masyarakat yang penting karena mortalitas dan morbiditasnya yang tinggi. Selain yayasan kanker Indonesia, saat ini sudah ada yayasan kesehatan kanker payudra Jakarta (YKPJ) yang juga peduli masalah kanker payudara. Organisasi ini mempunyai visi Jakarta bebas kanker payudara stadium lanjut tahun 2020. Organisasi ini memiliki banyak agenda termasuk penyuluhan akan pentingnya deteksi dini kanker payudara untuk meningkatkan kesadaran dan pengetahuan masyarakat (Setiati, 2009).

Penyebab spesifik kanker payudara masih belum diketahui, tetapi terdapat banyak faktor yang diperkirakan mempunyai pengaruh terhadap terjadinya tingginya kejadian kanker payudara, faktor tersebut diantaranya seperti: letak geografis, usia menarche dini, paritas yang rendah, masa laktasi, usia, obesitas dan genetik atau ada riwayat anggota keluarga dengan kanker payudara (Olfah, 2013).

Berdasarkan penelitian yang dilakukan Anggorowati (2013) tentang faktor risiko yang berhubungan dengan kejadian kanker payudara di RSUD Kudus Tahun 2010, hasil penelitian menunjukkan faktor yang berhubungan dengan kejadian kejadian kanker payudara adalah obesitas $(\mathrm{p}=0,00 ; \mathrm{OR}=4,49 ; \mathrm{CI}=2,01-10,02)$, usia melahirkan anak pertama $(\mathrm{p}=0,00$; $\mathrm{OR}=$ $4,99 ; \mathrm{CI}=1,90-13,87)$, riwayat pemberian ASI $(\mathrm{p}=0,00 ; \mathrm{OR}=5,49 ; \mathrm{CI}=2,05-14,74)$, dan usia menarche $(\mathrm{p}=0,00 ; \mathrm{OR}=6,66 ; \mathrm{CI}=2,84-15,65)$. Simpulan penelitian adalah faktor yang berhubungan dengan kejadian kejadian kanker 
payudara adalah obesitas, usia melahirkan anak pertama, riwayat pemberian ASI, dan usia menarche.

Penanganan kanker payudara bergantung pada jenis sel secara histopatologis, tahapan penyakit dan gambaran klinis lain. Klinisi umumnya melakukan rangkaian pembedahan, radiasi, dan kemoterapi (Norwitz dan Schorge, 2008).

Hasil pra survey yang dilakukan peneliti diperoleh data pada tahun 2014 kejadian kanker payudara di Rumah Sakit Umum Daerah dr. H. Abdul Moeloek Bandar Lampung sebanyak 1.347 orang, sedangkan data rawat jalan selama tahun 2014 sebanyak 3.500 orang. Pengambilan Rumah Sakit Umum Daerah dr. H. Abdul Moeloek Bandar Lampung sebagai tempat penelitian karena Rumah Sakit Umum Daerah dr. H. Abdul Moeloek Bandar Lampung merupakan rumah sakit rujukan terutama bagi penderita kanker payudara dari seluruh rumah sakit yang ada di Provinsi Lampung dan adanya peningkatan jumlah pasien kanker payudara dari tahun ke tahun.

\section{METODE PENELITIAN}

Jenis penelitian ini menggunakan metode kuantitatif dengan rancangan penelitian cross sectional. Populasi penelitian semua pasien yang mengunjungi Rumah Sakit baik rawat jalan selama periode penelitian sebanyak 1.347 orang. Sampel penelitian adalah 99 orang. Tehnik pengambilan sampel menggunakan metode simple random sampling. Analisis data dilakukan dengan chi square dan regresi logistik.

\section{HASIL PENELITIAN}

1. Hubungan riwayat kanker payudara dengan kejadian kanker payudara

Tabel 1. Hubungan riwayat kanker payudara dengan kejadian kanker payudara

\begin{tabular}{|c|c|c|c|c|c|c|c|c|}
\hline \multirow{3}{*}{$\begin{array}{c}\text { Riwayat } \\
\text { kanker }\end{array}$} & \multicolumn{4}{|c|}{ Kanker payudara } & \multicolumn{2}{|c|}{ Total } & \multirow{3}{*}{$\begin{array}{c}p \\
\text { value }\end{array}$} & \multirow{3}{*}{$\begin{array}{c}\text { OR } \\
95 \% \mathrm{CI}\end{array}$} \\
\hline & \multicolumn{2}{|c|}{$\begin{array}{c}\text { Kanker } \\
\text { payudara }\end{array}$} & \multicolumn{2}{|c|}{$\begin{array}{c}\text { Tidak } \\
\text { kanker } \\
\text { payudara }\end{array}$} & \multirow[t]{2}{*}{$\mathrm{n}$} & \multirow[t]{2}{*}{$\%$} & & \\
\hline & $\mathrm{n}$ & $\%$ & $\mathrm{n}$ & $\%$ & & & & \\
\hline Ada & 33 & 84,6 & 6 & 15,4 & 39 & 100 & \multirow{3}{*}{0,000} & \multirow{3}{*}{$\begin{array}{c}10,214 \\
(3,687- \\
28,294)\end{array}$} \\
\hline $\begin{array}{l}\text { Tidak } \\
\text { ada }\end{array}$ & 21 & 35,0 & 39 & 65,0 & 60 & 100 & & \\
\hline Jumlah & 54 & 54,5 & 45 & 45,5 & 99 & 100 & & \\
\hline
\end{tabular}

Hasil uji statistik dengan chi square diperoleh $p$-value $=0,000$ yang berarti ada hubungan riwayat kanker payudara dengan kejadian kanker payudara di Rumah Sakit Umum Daerah dr. H. Abdul Moeloek Bandar Lampung tahun 2014. Kemudian diperoleh $\mathrm{OR}=10,214$ yang berarti responden yang mempunyai riwayat keluarga dengan kanker mempunyai risiko sebesar 10,214 kali mengalami kanker payudara bila dibandingkan dengan responden yang tidak mempunyai riwayat keluarga dengan kanker payudara.

\section{Hubungan faktor usia dengan kejadian kanker payudara}

Tabel 2. Hubungan faktor usia dengan kejadian kanker payudara

\begin{tabular}{|c|c|c|c|c|c|c|c|c|}
\hline \multirow{3}{*}{ Usia } & \multicolumn{4}{|c|}{ Kanker payudara } & \multicolumn{2}{|c|}{ Total } & \multirow{3}{*}{$\begin{array}{c}p \\
\text { value }\end{array}$} & \multirow{3}{*}{$\begin{array}{c}\text { OR } \\
95 \% \mathrm{Cl}\end{array}$} \\
\hline & \multicolumn{2}{|c|}{$\begin{array}{c}\text { Kanker } \\
\text { payudara }\end{array}$} & \multicolumn{2}{|c|}{$\begin{array}{c}\text { Tidak } \\
\text { kanker } \\
\text { payudara }\end{array}$} & \multirow[t]{2}{*}{$\mathrm{n}$} & \multirow[t]{2}{*}{$\%$} & & \\
\hline & $\mathrm{n}$ & $\%$ & $\mathrm{n}$ & $\%$ & & & & \\
\hline $\begin{array}{l}>50 \\
\text { tahun }\end{array}$ & 34 & 87,2 & 5 & 12,8 & 39 & 100 & \multirow{3}{*}{0,000} & \multirow{3}{*}{$\begin{array}{l}13,600 \\
(4,612- \\
40,103)\end{array}$} \\
\hline $\begin{array}{l}\leq 50 \\
\text { tahun }\end{array}$ & 20 & 33,3 & 40 & 66,7 & 40 & 100 & & \\
\hline Jumlah & 54 & 54,5 & 45 & 45,5 & 99 & 100 & & \\
\hline
\end{tabular}

Hasil uji statistik dengan chi square diperoleh $p$-value $=0,000$ yang berarti ada hubungan faktor usia dengan kejadian kanker payudara di Rumah Sakit Umum Daerah dr. H. Abdul Moeloek Bandar Lampung tahun 2014. Kemudian diperoleh $\mathrm{OR}=13,600$ yang berarti responden berusia $>50$ tahun mempunyai risiko sebesar 13,600 kali mengalami kanker payudara bila dibandingkan dengan responden yang berusia $\leq 50$ tahun.

\section{Hubungan faktor usia menarche dini dengan kejadian kanker payudara}

Tabel 3. Hubungan faktor usia menarche dini dengan kejadian kanker payudara

\begin{tabular}{|c|c|c|c|c|c|c|c|c|}
\hline \multirow{3}{*}{$\begin{array}{c}\text { Usia } \\
\text { menarche } \\
\text { dini }\end{array}$} & \multicolumn{4}{|c|}{ Kanker payudara } & \multicolumn{2}{|c|}{ Total } & \multirow{3}{*}{$\begin{array}{c}p \\
\text { value }\end{array}$} & \multirow{3}{*}{$\begin{array}{c}\text { OR } \\
95 \% \text { CI }\end{array}$} \\
\hline & \multicolumn{2}{|c|}{$\begin{array}{l}\text { Kanker } \\
\text { payudara }\end{array}$} & \multicolumn{2}{|c|}{$\begin{array}{c}\text { Tidak } \\
\text { kanker } \\
\text { payudara }\end{array}$} & \multirow[t]{2}{*}{$\mathrm{n}$} & \multirow[t]{2}{*}{$\%$} & & \\
\hline & $\mathrm{n}$ & $\%$ & $\mathrm{n}$ & $\%$ & & & & \\
\hline$<11$ tahun & 39 & 70,9 & 16 & 29,1 & 55 & 100 & \multirow{3}{*}{0,001} & \multirow{3}{*}{$\begin{array}{c}4,713 \\
(2,009- \\
11,056)\end{array}$} \\
\hline$\geq 11$ tahun & 15 & 34,1 & 29 & 65,9 & 44 & 100 & & \\
\hline Jumlah & 54 & 54,5 & 45 & 45,5 & 99 & 100 & & \\
\hline
\end{tabular}

Hasil uji statistik dengan chi square diperoleh $p$-value $=0,001$ yang berarti ada hubungan faktor usia menarche dini dengan kejadian kanker payudara di Rumah Sakit Umum Daerah dr. H. Abdul Moeloek Bandar Lampung tahun 2014. Kemudian diperoleh $\mathrm{OR}=4,713$ yang berarti responden berusia menarche dini $<11$ tahun mempunyai risiko sebesar 4,713 kali 
mengalami kanker payudara bila dibandingkan $\geq 11$ tahun. dengan responden yang berusia menarche dini

4. Hubungan faktor penggunaan kontrasepsi hormonal dengan kejadian kanker payudara

Tabel 4. Hubungan faktor penggunaan kontrasepsi hormonal dengan kejadian kanker payudara

\begin{tabular}{|c|c|c|c|c|c|c|c|c|}
\hline \multirow{3}{*}{$\begin{array}{c}\text { Penggunaan } \\
\text { kontrasepsi } \\
\text { hormonal }\end{array}$} & \multicolumn{4}{|c|}{ Kanker payudara } & \multicolumn{2}{|c|}{ Total } & \multirow{3}{*}{$p$ value } & \multirow{3}{*}{$\begin{array}{c}\text { OR } \\
95 \% \mathrm{Cl}\end{array}$} \\
\hline & \multicolumn{2}{|c|}{ Kanker payudara } & \multicolumn{2}{|c|}{$\begin{array}{c}\text { Tidak kanker } \\
\text { payudara }\end{array}$} & \multirow[t]{2}{*}{$\mathrm{n}$} & \multirow[t]{2}{*}{$\%$} & & \\
\hline & $\mathrm{n}$ & $\%$ & $\mathrm{n}$ & $\%$ & & & & \\
\hline$<10$ tahun & 40 & 72,7 & 15 & 27,3 & 55 & 100 & \multirow{3}{*}{0,000} & 5,714 \\
\hline$\geq 10$ tahun & 14 & 31,8 & 30 & 68,2 & 44 & 100 & & $(2,397-$ \\
\hline Jumlah & 54 & 54,5 & 45 & 45,5 & 99 & 100 & & $13,621)$ \\
\hline
\end{tabular}

Hasil uji statistik dengan chi square diperoleh $p$-value $=0,000$ yang berarti ada hubungan faktor penggunaan kontrasepsi hormonal dengan kejadian kanker payudara di Rumah Sakit Umum Daerah dr. H. Abdul Moeloek Bandar Lampung tahun 2014.
Kemudian diperoleh $\mathrm{OR}=5,714$ yang berarti responden yang menggunakan kontrasepsi hormonal $\geq 10$ tahun mempunyai risiko sebesar 5,714 kali mengalami kanker payudara bila dibandingkan dengan responden yang yang menggunakan kontrasepsi hormonal $<10$ tahun.

\section{Hubungan faktor obesitas dengan kejadian kanker payudara}

Tabel 5. Hubungan faktor obesitas dengan kejadian kanker payudara

\begin{tabular}{|c|c|c|c|c|c|c|c|c|}
\hline \multirow{3}{*}{ Obesitas } & \multicolumn{4}{|c|}{ Kanker payudara } & \multicolumn{2}{|c|}{ Total } & \multirow{3}{*}{$\begin{array}{c}p \\
\text { value }\end{array}$} & \multirow{3}{*}{$\begin{array}{c}\text { OR } \\
95 \% \mathrm{CI}\end{array}$} \\
\hline & \multicolumn{2}{|c|}{$\begin{array}{c}\text { Kanker } \\
\text { payudara }\end{array}$} & \multicolumn{2}{|c|}{$\begin{array}{c}\text { Tidak kanker } \\
\text { payudara }\end{array}$} & \multirow[t]{2}{*}{$\mathrm{n}$} & \multirow[t]{2}{*}{$\%$} & & \\
\hline & $\mathrm{n}$ & $\%$ & $\mathrm{n}$ & $\%$ & & & & \\
\hline Obesitas & 34 & 68,0 & 16 & 32,0 & 50 & 100 & \multirow{3}{*}{0,012} & \multirow{3}{*}{$\begin{array}{c}3,081 \\
(1,353- \\
7,018)\end{array}$} \\
\hline $\begin{array}{l}\text { Tidak } \\
\text { obesitas }\end{array}$ & 20 & 40,8 & 29 & 59,2 & 49 & 100 & & \\
\hline Jumlah & 54 & 54,5 & 45 & 45,5 & 99 & 100 & & \\
\hline
\end{tabular}

Hasil uji statistik dengan chi square diperoleh $p$-value $=0,012$ yang berati ada hubungan faktor obesitas dengan kejadian kanker payudara di Rumah Sakit Umum Daerah dr. H. Abdul Moeloek Bandar Lampung tahun 2014. Kemudian diperoleh $\mathrm{OR}=3,081$ yang berarti

\section{Analisis Multivariat}

Tabel 6. Analisis Multivariat

\begin{tabular}{llcc}
\hline $\mathbf{N}$ & \multicolumn{1}{c}{ Variabel } & p-value & OR \\
$\mathbf{0}$ & & & \\
\hline 1 & Riwayat kanker & 0,000 & 10,275 \\
\hline 2 & Usia & 0,000 & 12,769 \\
\hline & $\begin{array}{l}\text { Penggunaan } \\
\text { kontrasepsi hormonal }\end{array}$ & 0,004 & 5,400 \\
\hline
\end{tabular}

Tidak ada variabel yang mempunyai nilai $p$-value $>0,05$ sehingga tidak ada variabel yang harus dikeluarkan dari model. Interprestasi hasil pemodelan yaitu faktor yang paling berhubungan responden obesitas mempunyai risiko sebesar 3,081 kali mengalami kanker payudara bila dibandingkan dengan responden yang tidak obesitas.

dengan kejadian kanker payudara di Rumah Sakit Umum Daerah dr. H. Abdul Moeloek Bandar Lampung tahun 2014 adalah faktor usia dengan $\mathrm{OR}=12,769$.

\section{Uji Interaksi}

Tabel 7. Uji Interaksi

\begin{tabular}{ccccc}
\hline Model & $\mathrm{R}$ & $\begin{array}{c}\mathrm{R} \\
\text { Square }\end{array}$ & $\begin{array}{c}\text { Adjusted } \\
\mathrm{R} \\
\text { Square }\end{array}$ & $\begin{array}{c}\text { Std. } \\
\text { Error of } \\
\text { the } \\
\text { Estimate }\end{array}$ \\
\hline 1 & 0,703 & 0,494 & 0,467 & 0,365 \\
\hline
\end{tabular}

Pada output model summary, koefisien determinasi besarnya adjusted $R^{2}$ terbesar 0,494 , 
hal ini berarti 49,4\% variasi kunjungan masyarakat yang dapat dijelaskan oleh variasi variabel independen riwayat kanker, usia, usia menarche dini, penggunaan kontrasepsi hormonal, dan obesitas. Sedangkan sisanya $(100 \%-49,4 \%=50,6 \%)$ dijelaskan oleh sebabsebab lain di luar model.

Tabel 8. Uji Standar Coefficients

\begin{tabular}{lcccccc}
\hline \multirow{2}{*}{ Variabel } & \multicolumn{2}{c}{$\begin{array}{c}\text { Unstandardized } \\
\text { Coefficients }\end{array}$} & $\begin{array}{c}\text { Standardized } \\
\text { Coefficients }\end{array}$ & \multirow{2}{*}{ S } & Sig. \\
\cline { 2 - 5 } & $\mathrm{B}$ & $\begin{array}{c}\text { Std. } \\
\text { Error }\end{array}$ & Beta & & \\
\hline (Constant) & $-0,142$ & 0,074 & & - & 0,059 \\
& & & & 1,911 & \\
\hline $\begin{array}{l}\text { Riwayat } \\
\text { kanker }\end{array}$ & 0,318 & 0,082 & 0,312 & 3,883 & 0,000 \\
\hline Usia & 0,384 & 0,079 & 0,377 & 4,853 & 0,000 \\
\hline $\begin{array}{l}\text { Usia } \\
\text { menarche } \\
\text { dini }\end{array}$ & 0,116 & 0,082 & 0,116 & 1,418 & 0,160 \\
\hline $\begin{array}{l}\text { Penggunaan } \\
\text { kontrasepsi } \\
\text { hormonal }\end{array}$ & 0,212 & 0,085 & 0,212 & 2,511 & 0,014 \\
\hline Obesitas & 0,050 & 0,081 & 0,051 & 0,617 & 0,538 \\
\hline
\end{tabular}

Pada output coefficient, menunjukkan bahwa koefisien obesitas sebesar 0,461 dan koefisien usia menarche dini sebesar 0,538 dan 0,160 jadi tidak signifikan karena lebih besar daripada 0,05 atau 0,10. Keputusannya variabel obesitas dan usia menarche dini bukan merupakan variabel moderating.

\section{PEMBAHASAN}

\section{Hubungan riwayat kanker payudara dengan kejadian kanker payudara}

Hasil uji statistik dengan chi square diperoleh $p$-value $=0,000$ yang berarti ada hubungan riwayat kanker payudara dengan kejadian kanker payudara di Rumah Sakit Umum Daerah dr. H. Abdul Moeloek Bandar Lampung tahun 2014. Kemudian diperoleh $\mathrm{OR}=10,214$ yang berarti responden yang mempunyai riwayat keluarga dengan kanker mempunyai risiko sebesar 10,214 kali mengalami kanker payudara bila dibandingkan dengan responden yang tidak mempunyai riwayat keluarga dengan kanker payudara. Berdasarkan uraian di atas, maka menurut peneliti kerentanan bawaan atau turunan kanker payudara pada umumnya tak disadari oleh pasien yang memiliki riwayat keluarga tersebut, hal ini ditunjukkan penderita kanker yang orang tuanya pernah menderita kanker payudara. Jika seorang wanita telah menderita kanker pada satu sisi payudaranya, maka risiko terkena kanker bagi payudara lagi yang lain atau terjadi kekambuhan pada lokasi yang terkena kanker sebelumnya adalah tinggi

\section{Hubungan faktor usia dengan kejadian kanker payudara}

Hasil uji statistik dengan chi square diperoleh $p$-value $=0,000$ yang berarti ada hubungan faktor usia dengan kejadian kanker payudara di Rumah Sakit Umum Daerah dr. H. Abdul Moeloek Bandar Lampung tahun 2014. Kemudian diperoleh $\mathrm{OR}=13,600$ yang berarti responden berusia $>50$ tahun mempunyai risiko sebesar 13,600 kali mengalami kanker payudara bila dibandingkan dengan responden yang berusia $\leq 50$ tahun. Berdasarkan uraian di atas, maka menurut peneliti umur seorang wanita merupakan faktor risiko yang memhubungani terjadinya kanker payudara. Hal ini terjadi karena semakin bertambahnya umur, maka jumlah kumulatif eksposur yang diterima sepanjang umur tersebut semakin tinggi pula, selain itu secara fisiologi terjadi penurunan fungsi-fungsi organ dan menurunnya daya tahan tubuh.

\section{Hubungan faktor usia menarche dini dengan kejadian kanker payudara}

Hasil uji statistik dengan chi square diperoleh $p$-value $=0,001$ yang berarti ada hubungan faktor usia menarche dini dengan kejadian kanker payudara di Rumah Sakit Umum Daerah dr. H. Abdul Moeloek Bandar Lampung tahun 2014. Kemudian diperoleh $\mathrm{OR}=4,713$ yang berarti responden berusia menarche dini $<11$ tahun mempunyai risiko sebesar 4,713 kali mengalami kanker payudara bila dibandingkan dengan responden yang berusia menarche dini $\geq 11$ tahun. Berdasarkan uraian di atas, maka menurut peneliti wanita yang mengalami haid pertama pada umur kurang dari 14 tahun maka durasi eksposur estrogen makin panjang dan risiko terkena kanker payudara sedikit lebih tinggi. Pada saat seorang wanita mengalami haid pertama, maka dimulailah fungsi siklus ovarium yang menghasilkan estrogen. Jumlah eksposur estrogen dan progesteron pada seorang wanita selama masa hidupnya dipercaya merupakan faktor risiko. Lebih lama seorang wanita terekspos, maka risiko untuk terkena kanker payudara lebih tinggi pula. Selain saat mulai terekspos, maka keteraturan siklus menstruasi juga ikut berperan. Keteraturan siklus menggambarkan frekuensi eksposur, jadi semakin cepat seorang wanita mengalami haid yang teratur sejak haid pertamanya, maka wanita tersebut mendapatkan eksposur yang lebih tinggi dibandingkan wanita yang keteraturan haidnya 
lambat atau memiliki siklus menstruasi yang panjang

\section{Hubungan faktor penggunaan kontrasepsi hormonal dengan kejadian kanker payudara}

Hasil uji statistik dengan chi square diperoleh $p$-value $=0,000$ yang berarti ada hubungan faktor penggunaan kontrasepsi hormonal dengan kejadian kanker payudara di Rumah Sakit Umum Daerah dr. H. Abdul Moeloek Bandar Lampung tahun 2014. Kemudian diperoleh $\mathrm{OR}=5,714$ yang berarti responden yang menggunakan kontrasepsi hormonal $\geq 10$ tahun mempunyai risiko sebesar 5,714 kali mengalami kanker payudara bila dibandingkan dengan responden yang yang menggunakan kontrasepsi hormonal $<10$ tahun. Berdasarkan uraian di atas, maka menurut peneliti peran hormon steroid endogen tersebut menimbulkan pertanyaan lebih lanjut, yaitu apakah penggunaan hormon steroid eksogen seperti kontrasepsi oral atau pil KB juga berhubungan dengan risiko kanker payudara.

Hasil pengamatan sejumlah penelitian menunjukkan bahwa penggunaan kontrasepsi oral kombinasi menekan ovulasi sehingga mengurangi risiko kanker endometrium maupun ovarium, namun tidak mengurangi risiko kanker payudara. Ketiadaan efek protektif terhadap kanker payudara diduga karena terdapat interaksi antara penggunaan hormon steroid eksogen dan faktor-faktor lingkungan. Dari hasil penelitian ini diharapkan adanya peningkatan upaya promosi kesehatan dan srceening khususnya bagi wanita yang memiliki riwayat keluarga menderita kanker payudara dalam pemilihan dan penggunaan alat kontrasepsi yang tepat.

\section{Hubungan faktor obesitas dengan kejadian kanker payudara}

Hasil uji statistik dengan chi square diperoleh $p$-value $=0,012$ yang berati ada hubungan faktor obesitas dengan kejadian kanker payudara di Rumah Sakit Umum Daerah dr. H. Abdul Moeloek Bandar Lampung tahun 2014. Kemudian diperoleh $\mathrm{OR}=3,081$ yang berarti responden obesitas mempunyai risiko sebesar 3,081 kali mengalami kanker payudara bila dibandingkan dengan responden yang tidak obesitas. Berdasarkan uraian di atas, maka menurut peneliti bahwa resiko pada kegemukan akan meningkat karena meningkatnya sintesis estrogen pada timbunan lemak. Tingginya kadar estrogen akan berhubungan terhadap proliferasi jaringan payudara. Proliferasi yang berlebihan dan tidak adanya batas kematian sel akan menyebabkan sel membelah secara terus menerus. Melalui proses progresi maka terjadilah kanker payudara.

\section{SIMPULAN}

Berdasarkan hasil penelitian dan pembahasan, maka dapat diambil kesimpulan:

1. Kejadian kanker payudara di Rumah Sakit Umum Daerah dr. H. Abdul Moeloek Bandar Lampung tahun 2014 sebanyak 54 orang.

2. Faktor genetik penderita kanker payudara di Rumah Sakit Umum Daerah dr. H. Abdul Moeloek Bandar Lampung tahun 2014 sebanyak 39 orang.

3. Faktor usia $>50$ tahun penderita kanker payudara di Rumah Sakit Umum Daerah dr. H. Abdul Moeloek Bandar Lampung tahun 2014 sebanyak 39 orang.

4. Faktor usia menarche $<11$ tahun penderita kanker payudara di Rumah Sakit Umum Daerah dr. H. Abdul Moeloek Bandar Lampung tahun 2014 sebanyak 55 orang.

5. Faktor penggunaan kontrasepsi $<10$ tahun penderita kanker payudara di Rumah Sakit Umum Daerah dr. H. Abdul Moeloek Bandar Lampung tahun 2014 sebanyak 55 orang.

6. Faktor obesitas penderita kanker payudara di Rumah Sakit Umum Daerah dr. H. Abdul Moeloek Bandar Lampung tahun 2014 sebanyak 50 orang.

7. Ada hubungan riwayat kanker payudara dengan kejadian kanker payudara di Rumah Sakit Umum Daerah dr. H. Abdul Moeloek Bandar Lampung tahun 2014 dengan $p$ value $=0,000$ dan $\mathrm{OR}=10,214$.

8. Ada hubungan faktor usia dengan kejadian kanker payudara di Rumah Sakit Umum Daerah dr. H. Abdul Moeloek Bandar Lampung tahun 2014 -value $=0,000$ dan $\mathrm{OR}=13,600$

9. Ada hubungan menarche dini dengan kejadian kanker payudara di Rumah Sakit Umum Daerah dr. H. Abdul Moeloek Bandar Lampung tahun 2014 p-value $=0,001$ dan $\mathrm{OR}=4,713$.

10. Ada hubungan faktor penggunaan kontrasepsi dengan kejadian kanker payudara di Rumah Sakit Umum Daerah dr. H. Abdul Moeloek Bandar Lampung tahun 2014 pvalue $=0,012$ dan $\mathrm{OR}=5,714$.

11. Ada hubungan factor obesitas dengan kejadian kanker payudara di Rumah Sakit Umum Daerah dr. H. Abdul Moeloek Bandar 
Lampung tahun $2014 p$-value $=0,012$ dan OR $=3,081$.

12. Faktor yang paling berhubungan dengan kejadian kanker payudara di Rumah Sakit Umum Daerah dr. H. Abdul Moeloek Bandar Lampung tahun 2014 adalah faktor usia dengan $\mathrm{OR}=12,769$

\section{SARAN}

1. Bagi Responden

Responden diharapkan dapat meningkatkan pengetahuannya tentang SADARI dan kanker payudara yang bisa di dapat dari berbagai media cetak maupun elektronik dan juga penyuluhan-penyuluhan di tempat pelayanan kesehatan terdekat yakni tentang manfaat dan cara praktik SADARI yang benar, terutama dengan memperahtikan usia dimana usia $>50$ tahun merupakan usia paling rentan dengan kejadian kanker payudara.

2. Bagi Instansi Kesehatan RSUD dr. H. Abdul Moeloek Bandar Lampung

Diharapkan kepada intansi kesehatan terutama unit-unit pelayanan kesehatan terdekat dengan masyarakat untuk lebih meningkatkan program penyuluhan kesehatan khususnya tentang deteksi dini kanker payudara dengan cara memberikan penyuluhan kepada ibu-ibu dalam mencegah dan menanggulangi kanker payudara terutama dengan pemberian penyuluhan dan pemeriksaan atau deteksi dini kanker payudara yang diadakan secara periodik.

3. Ilmu Kesehatan Masyarakat

Bagi tenaga kesehatan dan peneliti diharapkan dapat memberikan informasi tentang bahaya kanker payudara dan praktik SADARI bagi wanita usia subur dan sebagai bahan untuk melaksanakan program bakti masyarakat dengan memberikan penyuluhan tentang arti pentingnya SADARI dan bahaya kanker payudara, selain penyuluhan dapat dilakukan dengan pemeriksaan rutin yang diadakan pada daerah-daerah yang sudah terdeteksi kanker payudara dengan melibatkan instansi kesehatan serta tokoh masyarakat yang ada di wilayahnya.

4. Peneliti lebih lanjut

Peneliti lebih lanjut yang melakukan penelitian sejenis diharapkan dapat melakukan penelitian dengan membuat analisis data yang lebih beragam dengan menghubungkan antara faktor-faktor yang belum dikaji dalam penelitian ini.

\section{DAFTAR PUSTAKA}

Anna, Maria Sirait dkk. 2009. Hubungan Kontrasepsi Pil dengan Kejadian Kanker Payudara. Jurnal Penelitian.

Ellis, E.O. dkk. 2003. Pathology and Genetik of Tumours of The Breast and Female Genital Organs / WHO Classification of Tumours: IARC Press, Washington P.10, 34-6.

Emy Rianti. 2012. Faktor-faktor yang Berhubungan dengan Risiko Kanker Payudara Wanita pada Pasien Rawat Jalan di Rumah Sakit (RS) Kanker Dharmais. Jakarta. Tesis.

Errol Norwitz dan John Schorge. 2008. At a Glance Obstetri Ginekologi. Edisi Kedua. Jakarta: EMS.

Kemenkes RI. Penderita Kanker Diperkirakan Menjadi Penyebab Utama Beban Ekonomi Terus Meningkat. Diakses tanggal 21 Maret 2013 dari http://www.Kemenkes.go.id

Kemenkes RI. 2013. Seminar Sehari Dalam Rangka Memperingati Hari Kanker
Sedunia 2013. Jakarta diakses melalui http://www.Kemenkes.go.id

Kristiyanasari, Weni. 2011. ASI. Menyusui dan Sadari. Yogyakarta: Nuha Medica.

Lee dkk. 2009. Kanker Payudara, Pencegahan dan Pengobatannya. Jakarta: Darras Book.

Linloln \& Wilensky. 2008. Kanker Payudara, Diagnosis dan Solusinya. Jakarta : Prestasi Pustaka Publisher.

Lindra Anggorowati. 2013. Faktor Risiko yang Berhubungan dengan Kejadian Kanker Payudara di RSUD Kudus Tahun 2010. Skripsi.

Marice Sihombing. 2013. Faktor Risiko Tumor Payudara pada Perempuan, Umur 2565 di Lima Kelurahan Kecamatan Bogor Tengah. Tesis.

Mulyani dan Nuryani. 2013. Kanker Payudara dan PMS pada Kehamilan. Jogjakarta : Nuha Medika.

Notoatmodjo. 2010. Metodologi Penelitian Kesehatan. Jakarta: Rineka Cipta. 
Olfah dkk. 2013. Kanker Payudara dan SADARI, Jogjakarta: Nuha Medika.

Pierce A.Grace \& Neil R.Borley. 2006. At a Glance Ilmu Bedah Edisi Ketiga. Jakarta: EMS.

RSAM Abdul Moeloek. 2014. Profil RSUD $d r$. H. Abdul Moeloek Provinsi Lampung. Bandar Lampung.

Sastroasmoro. 2011. Dasar-dasar Metodologi untuk Penelitian Klinis. Jakarta: Binarupa Aksara.

Sastrosudarmo. 2010. Kanker the Silent Killer. Edisi I. Jakarta: PT Setia Kawan Prima Garda.
Setiati, Eni. 2009. Waspadai 4 Kanker Ganas Pembunuh Wanita. Jogjakarta: Andi.

Tryggvadottir L, Tulinius H, Eyfjord JE, Sigurvinsson T. 2001. Dampak Menyusui dengan Menurunnya Risiko Kanker Payudara di Iceland AS. Jurnal Penelitian.

WHO. 2011. Breast Cancer Detection. Diakses tanggal 21 Oktober 2015 dari http://www.who.int/cancer/detection/breas tcancer/en/

Winkjosastro, H. 2009. Ilmu Kebidanan. Jakarta: EGC. 